\title{
ANALISIS PRODUKSI SERASAH MANGROVE DI PANTAI MANG KALOK KABUPATEN BANGKA
}

\author{
Arthur Muhammad Farhaby, Arinda Unigraha Utama \\ Jurusan Manajemen Sumberdaya Perairan, Universitas Bangka Belitung, \\ Kepulauan Bangka Belitung, Indonesia \\ E-mail : Amfarhaby88@gmail.com
}

Received February 2019, Accepted April 2019

\begin{abstract}
ABSTRAK
Ekositem mangrove merupakan ekosistem pesisir yang memiliki peran dan fungsi ekologis penting dalam menunjang sumber daya perairan dan perikanan. Keberadaan ekosistem mangrove yang lestari dan sehat tidak dapat dipisahkan oleh suplai kandungan bahan organik yang berasal dari serasah mangrove. Serasah merupakan guguran struktur vegetatif dan reproduktif yang disebabkan oleh faktor ketuaan, stress oleh faktor mekanik, ataupun kombinasi dari keduanya dan kematian serta kerusakan dari keseluruhan tumbuhan oleh iklim (hujan dan angin). Tujuan dari penelitian ini adalah untuk mengetahui produksi serasah daun mangrove, membandingkan produksi serasah beberap jenis mangrove yang dominan terdapat di Pantai Mang Kalok, serta mengetahui nilai parameter lingkungan yang berkaitan dengan serasah. Penelitan ini dilaksanakan pada bulan Januari-Maret 2018 bertempat di Pantai Mang Kalok, Kecamatan Sungailiat, Kabupaten Bangka. Metode yang umum digunakan untuk pengambilan produksi serasah adalah metode litter-trap (Jaring penampung serasah). Produksi serasah daun mangrove di Pantai Mang Kalok lebih banyak dihasilkan dari jenis Ceriops decandra dengan massa 185,7gr/m²/30hari dibandingkan dengan jenis Rhizophora mucronata yang hanya memproduksi $119,6 \mathrm{gr} / \mathrm{m}^{2} / 30$ hari. Adapun untuk total produksi serasah daun mangrove di Pantai Mang Kalok adalah 305,3 $\mathrm{gr} / \mathrm{m}^{2} / 30$ hari atau $10,17 \mathrm{gr} / \mathrm{m}^{2} /$ hari. Sedangkan parameter lingkungan menujukan kondisi perairan Pantai Mang Kalok masih baik dan dapat mendukung proses penyerapan bahan organik dari serasah daun mangrove.
\end{abstract}

Kata Kunci : Serasah, Mangrove, Pantai Mang Kalok

\section{ABSTRACT}

ANAL YSYS OF MANGROVE LITTER PRODUCTION ON MANG KALOK BEACH, BANGKA REGENCY. The mangrove ecosystem is a coastal ecosystem that has important ecological roles and functions in supporting marine resources and fisheries. The existence of a sustainable and 
healthy mangrove ecosystem cannot be separated by the supply of organic matter from mangrove litter. Litter is vegetative and reproductive structures avalanches caused by the factor of aging, stress by mechanical factors, or a combination of both and the death and destruction of the whole plant by the climate (rain and wind). The purpose of this study was to determine the production of mangrove leaf litter, compare the production of litter of several dominant types of mangrove found in Mang Kalok Beach, and to determine the value of environmental parameters related to litter. Research was conducted in January until March 2018 in Mang Kalok Beach, District Sungailiat, Bangka. A common method used for making the production of litter is litter-trap method (Net container litter). The production of mangrove leaf litter in Mang Kalok Beach is more produced from the type Ceriops decandra with a mass of $185.7 \mathrm{gr} / \mathrm{m}^{2} / 30$ days compared to the type of Rhizophora mucronata which only produces $119.6 \mathrm{gr} / \mathrm{m}^{2} / 30$ days. The total production of mangrove leaf litter at Mang Kalok Beach is $305.3 \mathrm{gr} / \mathrm{m}^{2} / 30$ days or $10.17 \mathrm{gr} / \mathrm{m}^{2} /$ day. While the environmental parameters show that the condition of Mang Kalok Beach is still good and can support the process of absorption of organic matter from mangrove leaf litter.

Keywords : Litter, Mangrove, Mang Kalok Beach

\section{PENDAHULUAN}

Ekosistem mangrove merupakan salah satu ekosistem yang mempunyai peran penting di wilayah pesisir Indonesia. Ekosistem ini memiliki banyak fungsi mendasar yang mampu mendukung kehidupan manusia maupun biota-biota yang berada di sekitarnya. Secara ekologis ekosistem ini berfungsi sebagai daerah memijah, daerah mencari makan serta daerah asuhan bagi berbagai macam organisme yang mempunyai nilai ekonomis (Bengen, 2003) Ekosistem mangrove dengan berbagai fungsi ekologisnya yang bersifat langsung sebagai penyedia unsur hara bagi biota yang terdapat pada ekosistem mangrove dan perairan sekitarnya, juga mempunyai fungsi jasa-jasa lingkungan. Beberapa fungsi pentingnya adalah melokalisir dan melarutkan berbagai bahan pencemaran, memperbaiki kualitas air, mencegah abrasi, penghasil oksigen, penyerap karbondioksida, sebagai biodiversity, mencegah tejadinya perubahan iklim global. Haris et al. (2012), menyatakan bahwa serasah mangrove merupakan penyuplai bahan organik terhadap kesuburan ekosistem mangrove, sehingga mampu menunjang kehidupan makhluk hidup di dalamnya.

Menurut Dharmawan et al. (2016), serasah daun sebagai komponen utama dalam produtivitas primer bakau merupakan sumber karbon penting dalam proses dekomposisi. Ekosistem mangrove dengan berbagai fungsi ekologisnya yang bersifat langsung sebagai penyedia unsur hara bagi biota yang terdapat pada ekosistem mangrove dan perairan sekitarnya, juga mempunyai fungsi jasa-jasa lingkungan. Beberapa fungsi pentingnya adalah melokalisir dan melarutkan berbagai 
bahan pencemaran, memperbaiki kualitas air, mencegah abrasi, penghasil oksigen, penyerap karbondioksida, sebagai biodiversity, mencegah tejadinya perubahan iklim global.

Pantai Mang Kalok merupakan salah satu kawasan pesisir di Kabupaten Bangka berupa kawasan eks tambang timah dan terkena dampak dari penambangan timah yang tidak ramah lingkungan. Pantai Mang kalok secara alami sudah memiliki tingkat keanekaragaman mangrove yang cukup tinggi. Keberlanjutan ekosistem mangrove di Pantai Mang kalok perlu dipertahankan sebab banyak organisme air yang menggunakan kawasan mangrove tersebut sebagai feeding ground, spawning ground dan nursery ground. Guna menunjang fungsi ekologis tersebut perlu diketahui secara detil mengenai produksi serasah daun mangrove di Pantai Mang Kalok berdasar jenis mangrove yang tumbuh di kawasan Pantai Mang kalok, serta mengetahui nilai parameter lingkungan yang berkaitan dengan produksi serasah mangrove tersebut.

\section{MATERI DAN METODE}

\section{Materi Penelitian}

Penelitan ini dilaksanakan pada bulan Januari-Maret 2018 bertempat di Pantai Mang Kalok, Kecamatan Sungailiat, Kabupaten Bangka. Aktivitas pengeringan dan perhitungan data dilakukan di Laboratorium Manajemen Sumberdaya Perairan, Universitas Bangka Belitung.
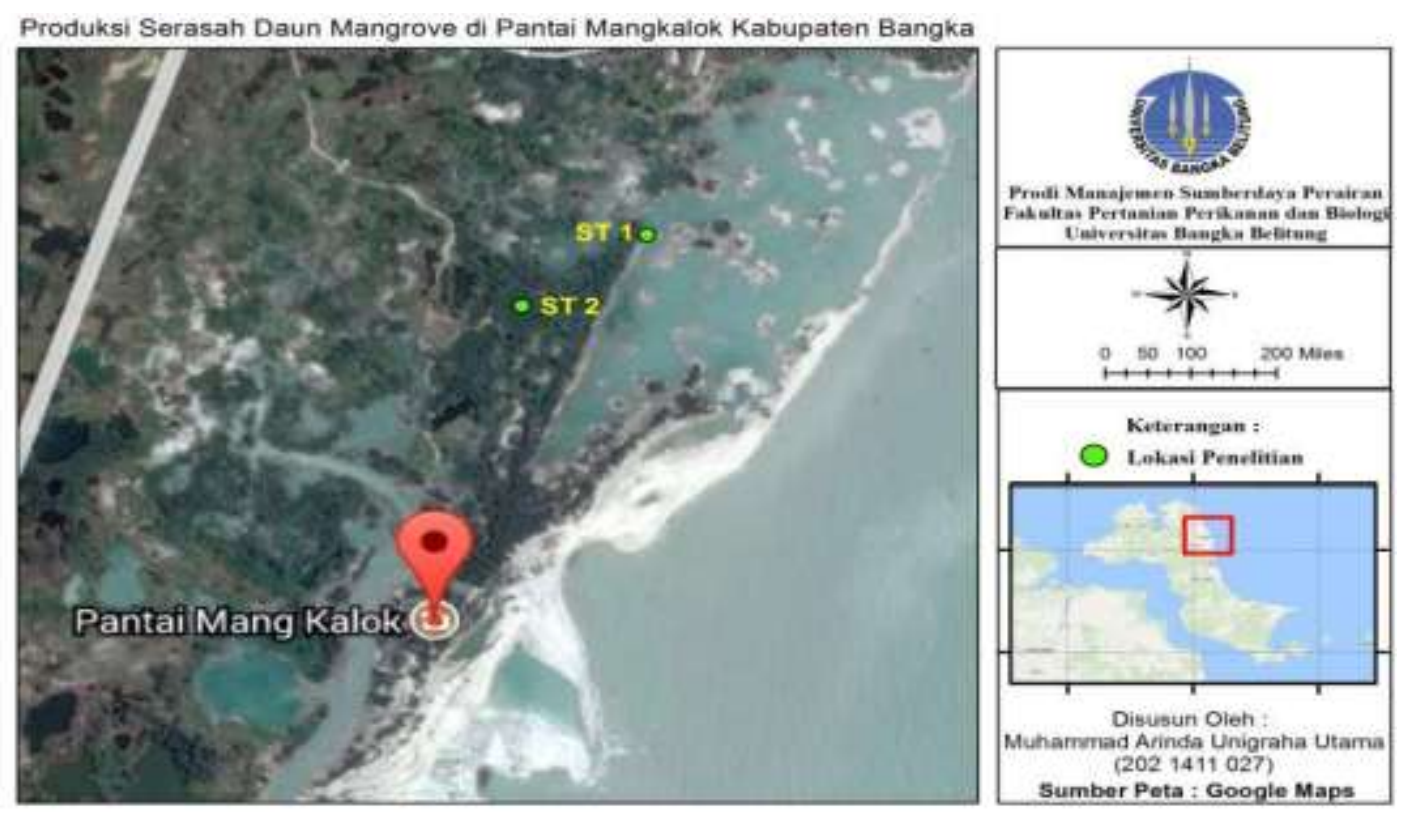

Gambar 1. Peta Lokasi Penelitian 


\section{Metode Penelitian}

Metode yang umum digunakan untuk pengambilan produksi serasah adalah metode litter-trap atau Jaring penampung serasah (Indriani, 2008).

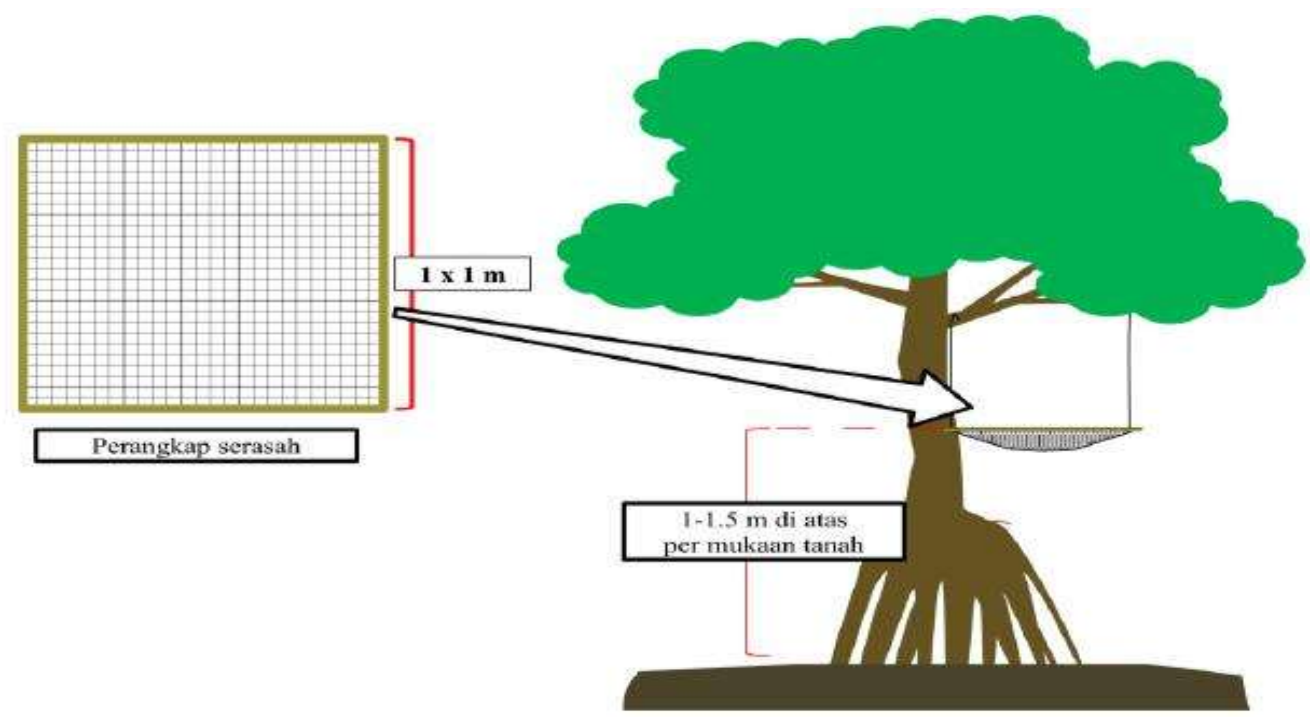

Gambar 2. Ilustrasi Pemasangan Jaring Perangkap Serasah

Penelitian untuk mengukur jumlah serasah yang dihasilkan ekosistem mangrove ini diawali dengan identifikasi jenis-jenis mangrove pada 2 stasiun penelitian yang ditentukan berdasarkan perbedaan karakteristik tertentu yaitu stasiun 1 pada muara yang terkena pengaruh pasang surut secara langsung dan stasiun 2 pada genangan air payau yang tidak berhubungan langsung dengan laut. Ditentukan pula dua substasiun pada masing-masing stasiun. Lalu dilakukan pemasangan jaring perangkap serasah (Litter trap) berukuran $1 \times 1 \mathrm{~m}^{2}$ sebanyak empat buah yang dipasang secara acak di bawah kanopi tegakan mangrove pada ketinggian 1,5 $\mathrm{m}$ di atas permukaan tanah, sehingga terhindar dari pengaruh air pasang (Affiandi, 1996). Secara alami, serasah yang jatuh dari pohon akan tertampung pada perangkap serasah (litter trap). Selanjutnya serasah yang tertampung dalam perangkap serasah diambil setiap 10 hari selama satu bulan (tiga kali), sampel serasah daun dikeringanginkan. Serasah dimasukan kedalam kantong plastik untuk ditimbang menggunakan timbangan digital guna diukur massanya. Selanjutnya serasah yang dikumpulkan, di oven selama 24 jam (sampai beratnya konstan) dengan suhu $85^{\circ} \mathrm{C}$ untuk menghilangkan kadar airnya sehingga didapatkan serasah dalam kondisi kering (Apdhan et a.l, 2012). Kemudian dilakukan kalkulasi massa serasah dalam waktu satu bulan untuk selanjutnya dilakukan pengkajian terkait produksi serasah daun mangrove di Pantai Mang Kalok.

Parameter lingkungan yang diambil dalam penelitian ini adalah terkait secara langsung dengan ekosistem mangrove meliputi suhu 
perairan $\mathrm{pH}$ perairan, salinitas, kelembaban udara, dan kadar oksigen terlarut di perairan (Aksornkoae, 1993)

Analisis data yang digunakan dalam penelitian ini menggunakan analisis deskriptif, dimana data yang didapat dari penelitian diolah secara deskriptif dalam bentuk table serta diagram.guna menunjukkan gambaran bagaimana kondisi riil di lapangan.

\section{HASIL DAN PEMBAHASAN}

\section{Jenis Mangrove di Pantai Mang kalok}

Berdasarkan hasil pengamatan di lokasi penelitian diketemukan dua spesies mangrove yaitu Rhizophora mucronata dan Ceriops decandra. Menurut Dharmawan et al. (2016), komunitas bakau umumnya didominasi oleh spesies Rhizophora sp. yang ditemukan di semua zona (dekat dengan laut, ataupun kearah aliran sungai). Substrat berlumpur kaya bahan organik memungkinkan spesies ini tumbuh dengan baik, spesies ini juga memiliki toleransi salinitas yang lebih lebar (Nybakken,1986).

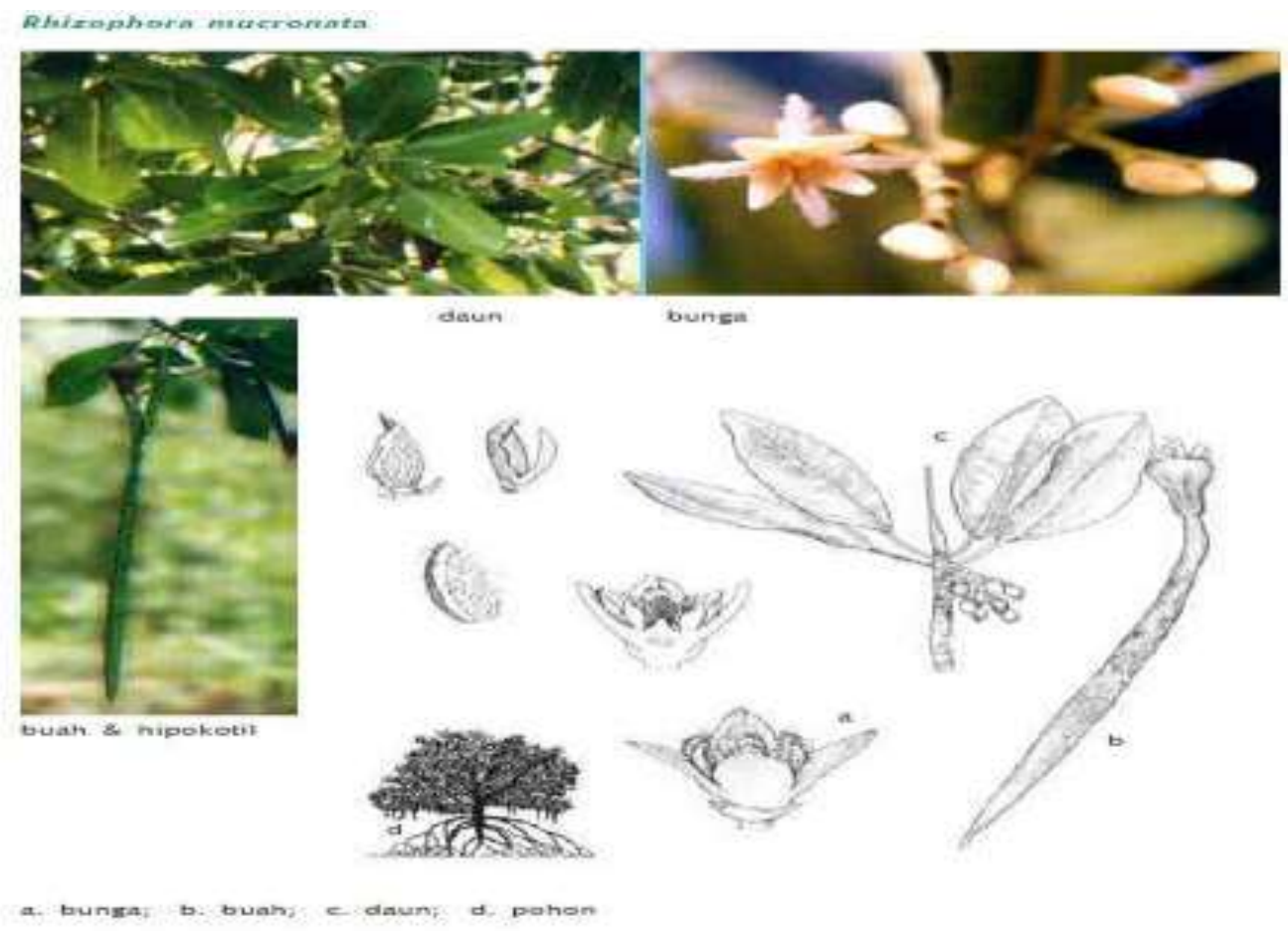

\section{Gambar 3.Rhizophora mucronata}

Jenis Rhizophora mucronata, menurut Rusila, et al. (2006), memiliki nama lain yaitu Bangka itam, dongoh korap, bakau hitam, bakau korap, bakau merah, lolaro. Mangrove jenis ini memiliki ketinggian pohon mencapai $27 \mathrm{~m}$, jarang melebihi $30 \mathrm{~m}$. Batangnya memiliki diameter hingga $70 \mathrm{~cm}$ dengan kulit kayu berwarna gelap hingga hitam dan terdapat celah horizontal. Akar tunjang dan akar udara yang tumbuh dari 
percabangan bagian bawah. Daunnya berkulit, Gagang daun berwarna hijau dengan panjang berkisaran antara 2,5-5,5 cm. Pinak daunnya terletak pada pangkal gagang daun dengan kisaran ukuran $5,5-8,5 \mathrm{~cm}$. Daunnya berbentuk elips melebar hingga bulat memanjang dengan ujung meruncing berukuran 11-23 x 5-13 cm (Gambar 3).

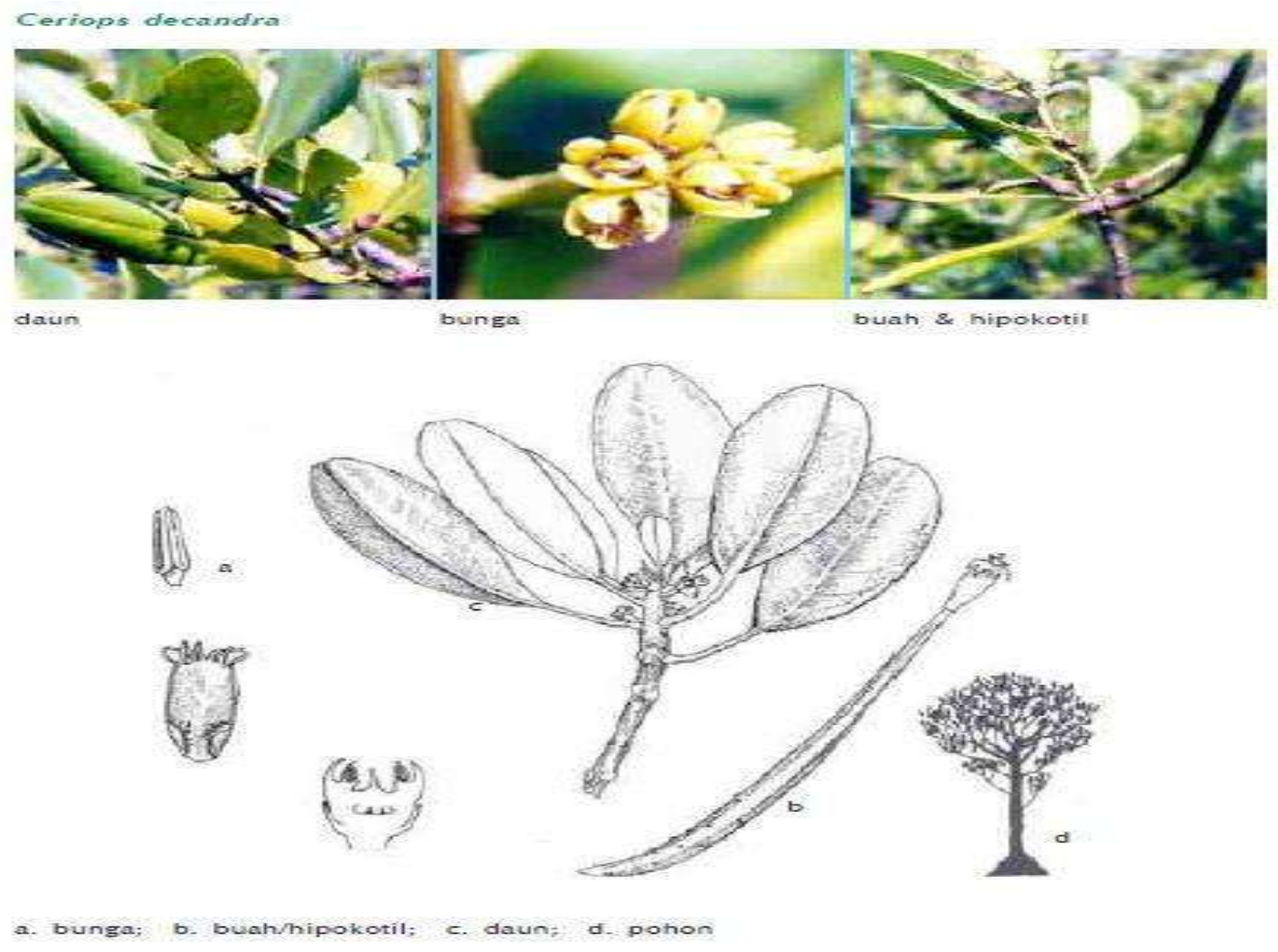

Gambar 4. Gambar Ceriops decandra

Jenis Ceriops decandra memiliki nama lokal seperti Tengal, Tengar, Tingi, Tinci, Palun, Parun, bido-bido, kenyonyong, luru. Mengrove ini berupa pohon atau semak kecil dengan ketinggian hingga $15 \mathrm{~m}$. Kulit kayu berwarna coklat, jarang berwarna abu-abu atau putih kotor, memiliki permukaan halus, rapuh dan bagian pangkalnya menggelembung. Daunnya hijau mengkilap berbentuk elips bulat memanjang dengan ujung membundar berukuran 3-10 x 1-4,5 cm. Namun, bentuk dan ukuran daun sangat beragam karena bergantung dengan kadar pencahayaan dan air tempat mangrove jenis ini tumbuh (Rusila, et al., 2006).

\section{Berat Basah dan Berat Kering Serasah Mangrove}

Pantai Mang Kalok merupakan salah satu pantai yang menjadi objek wisata andalan di Kabupaten Bangka. Selain menawarkan aktivitas wisata pantai, juga terdapat komunitas mangrove di kawasan ini. Tegakan-tegakan mangrove di Pantai Mang Kalok tumbuh secara alami 
dan tumbuh dari aktivitas budidaya/ penanaman anakan mangrove yang dilakukan oleh masyarakat. Banyak jenis mangrove di Pantai Mang Kalok, mulai dari Mangrove mayor, minor, hingga assosiasi seperti Nipah. Adanya ekosistem mangrove, menjadikan kawasan ini sebagai salah satu tempat penyerap karbon dan penghasil oksigen yang sangat penting bagi kehidupan.

Menurut Farhaby (2011), Produksi serasah daun sebagian kecil terbawa arus dan sebagian besar tetap di daratan atau di hutan. Serasah daun yang tertinggal di daratan menjadi makanan binatang dan sebagian besar akan mengalami penguraian sebagian atau sepenuhnya yang dilakukan oleh jasad-jasad renik maupun bakteri. Semakin tinggi produksi serasah maka semakin tinggi pula produktivitas di hutan mangrove. Berat basah dan berat kering serasah hasil penelitian dapat dilihat pada Tabel 1 dan Tabel 2.

Tabel 1. Berat Basah Serasah Mangrove Pantai Mang Kalok

\begin{tabular}{|c|c|c|c|c|c|c|}
\hline \multirow[t]{2}{*}{$\begin{array}{l}\text { Sta- } \\
\text { siun }\end{array}$} & \multirow[t]{2}{*}{$\begin{array}{l}\text { Sub } \\
\text { Stasiun }\end{array}$} & \multirow[t]{2}{*}{$\begin{array}{l}\text { Jenis } \\
\text { Mangrove }\end{array}$} & \multicolumn{3}{|c|}{$\begin{array}{l}\text { Serasah Duan Mangrove } \\
\left(\mathrm{g} / \mathrm{m}^{2} / 30 \text { hari }\right)\end{array}$} & \multirow[t]{2}{*}{ Jumlah } \\
\hline & & & Minggu & Minggu & $\underset{\text { III }}{\text { Minggu }}$ & \\
\hline \multirow[t]{2}{*}{1} & 1.1 & Rhizophora & 17,4 & 19 & 20,4 & 56,8 \\
\hline & 1.2 & $\begin{array}{l}\text { mucronata } \\
\text { Ceriops } \\
\text { decandra }\end{array}$ & 16 & 20,6 & 17,7 & 54,3 \\
\hline \multirow[t]{2}{*}{2} & 2.1 & $\begin{array}{l}\text { Rhizophora } \\
\text { mucronata }\end{array}$ & 18 & 25,4 & 19,4 & 62,8 \\
\hline & 2.2 & $\begin{array}{l}\text { Ceriops } \\
\text { decandra }\end{array}$ & 42,2 & 45,1 & 44,1 & 131,4 \\
\hline \multicolumn{3}{|c|}{ Jumlah Keseluruhan } & 93,6 & 110,1 & 101,6 & 305,3 \\
\hline
\end{tabular}

Tabel 2. Berat kering serasah mangrove pantai mang kalok

\begin{tabular}{|c|c|c|c|c|c|c|}
\hline \multirow[t]{2}{*}{$\begin{array}{l}\text { Sta- } \\
\text { siun }\end{array}$} & \multirow[t]{2}{*}{$\begin{array}{l}\text { Sub } \\
\text { Stasiun }\end{array}$} & \multirow[t]{2}{*}{$\begin{array}{c}\text { Jenis } \\
\text { Mangrove }\end{array}$} & \multicolumn{3}{|c|}{$\begin{array}{c}\text { Serasah Duan Mangrove } \\
\left(\mathrm{g} / \mathrm{m}^{2} / 30 \text { hari }\right)\end{array}$} & \multirow[t]{2}{*}{ Jumlah } \\
\hline & & & Minggu & Minggu & $\begin{array}{l}\text { Minggu } \\
\text { III }\end{array}$ & \\
\hline \multirow[t]{2}{*}{1} & 1.1 & $\begin{array}{l}\text { Rhizophora } \\
\text { mucronata }\end{array}$ & 21,7 & 26,6 & 23,8 & 72,1 \\
\hline & 1.2 & $\begin{array}{l}\text { Ceriops } \\
\text { decandra }\end{array}$ & 23,2 & 25,4 & 28,4 & 77 \\
\hline 2 & 2.1 & $\begin{array}{l}\text { Rhizophora } \\
\text { mucronata }\end{array}$ & 23,3 & 37,8 & 33 & 94,1 \\
\hline
\end{tabular}




\begin{tabular}{|c|c|c|c|c|c|}
\hline 2.2 & $\begin{array}{l}\text { Ceriops } \\
\text { decandra }\end{array}$ & 60,4 & 61 & 55,8 & 177,2 \\
\hline Jumlah K & eluruhan & 128,6 & 150,8 & 141 & 420,4 \\
\hline
\end{tabular}

Berdasarkan data hasil penelitian berat basah serasah mangrove sebagaimana ditunjukan (Tabel.1) yaitu massa serasah daun mangrove yang didapat dari jaring perangkap tanpa dioven, selama satu bulan menunjukan bahwa pada stasiun 1 (muara sungai), Rhizophora mucronata menghasilkan serasah daun lebih sedikit yaitu $72,1 \mathrm{gr} / \mathrm{m}^{2}$ dibandingkan dengan jenis Ceriops decandra dengan massa $77 \mathrm{gr} / \mathrm{m}^{2}$. Sementara pada stasiun 2 juga sama dimana jenis Rhizophora mucronata menghasilkan serasah daun lebih sedikit yaitu $94,1 \mathrm{gr} / \mathrm{m}^{2}$ dibandingkan dengan jenis Ceriops decandra dengan massa $177,2 \mathrm{gr} / \mathrm{m}^{2}$. Adapun keseluruhan jumlah serasah yang dihasilkan dari keempat sub stasiun adalah $420,4 \mathrm{gr} / \mathrm{m}^{2} / 30$ hari.

Nontji (1987) menyatakan bahwa laju produksi serasah dipengaruhi oleh Semakin tinggi kerapatan pohon, maka semakin tinggi pula produksi serasahnya, begitu juga sebaliknya semakin rendah kerapatan pohon maka semakin rendah produksi serasahnya. Selain tingkat kerapatan, laju produksi serasah juga dipengaruhi oleh jenis mangrove dan umurnya. Jenis mangrove yang berbeda akan memiliki laju produksi serasah yang berbeda pula. Data berat kering serasah daun mangrove yang tercantum dalam (Tabel.2) menujukan bahwa pada stasiun 1 jenis Rhizophora mucronata menghasilkan serasah daun lebih banyak yaitu $56,8 \mathrm{gr} / \mathrm{m}^{2}$ dibandingkan dengan jenis Ceriops decandra dengan massa $54,3 \mathrm{gr} / \mathrm{m}^{2}$. Sementara pada stasiun 2, jenis Rhizophora mucronata menghasilkan serasah daun lebih sedikit yaitu $62,8 \mathrm{gr} / \mathrm{m}^{2}$ dibandingkan dengan jenis Ceriops decandra dengan massa $131,4 \mathrm{gr} / \mathrm{m}^{2}$. Adapun keseluruhan jumlah serasah yang dihasilkan dari keempat sub stasiun adalah $305,3 \mathrm{gr} / \mathrm{m}^{2} / 30 \mathrm{hari}$. Hal tersebut dapat terjadi karena dipengaruhi beberapa faktor alam yang tidak dapat dikontrol seperti kondisi cuaca, pengaruh arah dan kecepatan angin, gerakan-gerakan pada tegakan mangrove oleh burung-burung atau primata dan pengaruh aktivitas manusia. Perbedaan yang didapatkan disebabkan adanya perbedaan ke rapatan, umur dari tumbuhan, dan kesuburan tegakan mangrove. Hal ini sesuai menurut Soenardjo (1999), semakin tua tumbuhan maka produksi serasahnya semakin menurun, begitu pula sebaliknya.

Berdasarkan data-data di atas, dapat dinyatakan bahwa produksi serasah daun mangrove di Pantai Mang Kalok di daerah muara didominasi oleh Rhizophora mucronata sedangkan di daerah payau (pertengahan) lebih didominasi oleh Ceriops decandra

Tingginya kontribusi daun terhadap produktifitas serasah yang dihasilkan terkait dengan salah satu bentuk adaptasi tumbuhan mangrove untuk mengurangi kehilangan air agar dapat bertahan hidup pada kondisi kadar garam tinggi. Menurut Murdiyanto (2003), terdapat 3 cara mangrove untuk bertahan terhadap air garam: (i) Mangrove menghindari penyerapan garam berlebihan dengan cara menyaring melalui bagian akarnya, (ii) Secepatnya mengeluarkan garam yang masuk ke dalam sistem 8 
pepohonan melalui daun, (iii) Menumpuk kelebihan garam pada kulit pohon dan daun tua lalu segera digugurkan. Persentase guguran serasah daun berkorelasi positif dengan salinitas perairan ekosistem mangrove, semakin tinggi salinitas perairan maka semakin tinggi pula produksi serasah mangrove. Hal ini sesuai dengan hasil penelitian Affiandi (1996), persentase guguran serasah daun mangrove sebesar $57 \%$ di kawasan sungai, $65 \%$ di kawasan tambak, dan $81 \%$ dikawasan rawa hutan payau $\mathrm{RPH}$ Tritih Cilacap.

Serasah mangrove yang dihasilkan berupa daun merupakan serasah yang paling penting peranannya dibandingkan dengan organ lain. Menurut Sukardjo (2014) menyatakan dalam aliran energi hutan mangrove, daun memegang peranan penting karena merupakan sumber nutrisi bagi organisme.

Selain faktor internal dari mangrove, guguran serasah juga dipengaruhi faktor eksternal berupa parameter fisik lingkungan. data parameter lingkungan selama penelitian berlangsung tertera pada tabel berikut.

Tabel 3. Hasil pengukuran parameter lingkungan Pantai Mang Kalok

\begin{tabular}{ccccc}
\hline \multirow{2}{*}{ Parameter } & \multicolumn{2}{c}{ Stasiun 1 } & \multicolumn{2}{c}{ Stasiun 2 } \\
\cline { 2 - 5 } & Sub 1 & Sub 2 & Sub 1 & Sub 2 \\
\hline Suhu $\left({ }^{\circ} \mathrm{C}\right)$ & 30,7 & 35 & 32 & 30.9 \\
PH & 7,9 & 8,4 & 7,6 & 7,7 \\
Salinitas & 27 & 28 & 19 & 16 \\
DO & 6,2 & 5,6 & 5 & 5,2 \\
Kelembaban Udara & 70 & 65 & 65 & 70 \\
\hline
\end{tabular}

Suhu dan kelembaban udara mempengaruhi jatuhan serasah tumbuhan. Naiknya suhu udara akan menyebab-kan menurunnya kelembaban udara sehingga transpirasi akan meningkat, dan untuk menguranginya maka daun harus segera digugurkan (Salisbury dan Ross, 1992). Dari hasil pengukuran paremeter fisik lingkungan didapatkan suhu udara $27,8-31,7^{\circ} \mathrm{C}$ dengan tingkat kelembaban $50-88 \%$.

Menurut Farhaby (2017) tumbuhan mangrove akan mengugurkan daun segarnya di bawah suhu optimum dan menghentikan produksi daun baru apabila suhu lingkungan di atas suhu optimum. Penelitian Farhaby (2017) menunjukkan bahwa temperatur optimum untuk pertumbuhan $R$. Mucronata dan Ceriops spp. adalah $26-30^{\circ} \mathrm{C}$, dan Bruguera spp. adalah $27^{\circ} \mathrm{C}$. Hasil penelitian menunjukkan bahwa Suhu hutan mangrove Mang kalok $\left(27,8-31,7^{\circ} \mathrm{C}\right)$ masih merupakan suhu yang optimum bagi famili Rhizophoraceae. 


\section{KESIMPULAN}

Produksi serasah daun mangrove di Pantai Mang Kalok lebih banyak dihasilkan dari jenis Ceriops decandra dengan massa $185,7 \mathrm{gr} / \mathrm{m}^{2} / 30$ hari dibandingkan dengan jenis Rhizophora mucronata yang hanya memproduksi $119,6 \mathrm{gr} / \mathrm{m}^{2} / 30$ hari. Total produksi serasah daun mangrove di Pantai Mang Kalok adalah 305,3 gr/m $/ 3$ hari atau 10,17 $\mathrm{gr} / \mathrm{m}^{2} /$ hari. Parameter fisik lingkungan tidak memberikan pengaruh yang nyata terhadap produksi serasah hutan mangrove di Pantai Mangkalok.

\section{DAFTAR PUSTAKA}

Affiandi, M. 1996. Produksi dan Laju Penghancuran Serasah di Hutan Mangrove Alami dan Binaan Cilacap Jawa Tengah. [Tesis]. Bandung: ITB.

Aksornkoae, S. 1993. Ecology and Management of Mangroves. The IUCN Wetlands Programme. Bangkok. Thailand

Apdhan D., Aras M. dan Zulkifli. 2012. Produksi Dan Kandungan Karbon Serta Laju Dekomposisi Serasah Xylocarpus Sp Di Perairan Sungai Mesjid Dumai, Riau. Jurnal IImu Kelautan. Universitas Riau

Bengen, D. G. 2003. Pedoman Teknis Pengenalan dan Pengelolaan Ekosistem Mangrove. PKSPL. IPB. Bogor

Dharmawan, I. W. E, Zamani. N. P, dan Madduppa. H. H., 2016. Laju Dekomposisi Serasah Daun di Ekosistem Bakau Pulau Kelong, Kabupaten Bintan. Oseanologi dan Limnologi di Indonesia. 1 (1) : 110.

Farhaby, A.M. 2011. Kerapatan Tegakan Mangrove dan Kelimpahan Kepiting Bakau (Scylla Sp) di Kawasan Ujung Alang Segara Anakan Cilacap. Universitas Diponegoro

---.-. 2017. Kajian Karakteristik Biometrika Kepiting Bakau (Scylla sp) di Kabupaten Pemalang, Studi kasus di Desa Mojo Kecamatan Ulujami. Akuatik Jurnal Sumberdaya Perairan, Vol 11, No 1 , hlm. $48-53$

Haris.A, Damar.A, Bengen. D. G, dan Yulianda. F., 2012. Produksi Serasah Mangrove Dan Kontribusinya Terhadap Perairan Pesisir Kabupaten Sinjai. Octopus 1 (1) : 13-18.

Indriani.Y., 2008. Produksi Dan Laju Dekomposisi Serasah Daun Mangrove Api-Api (Avicennia Marina Forssk. Vierh) Di Desa Lontar, Kecamatan Kemiri, Kabupaten Tangerang, Provinsi Banten. Jurnal IImu-ilmu Perairan dan Perikanan Indonesia. Institut Pertanian Bogor. 
Murdiyanto, B. 2003. Mengenal, Memelihara, dan Melestarikan Ekosisitem Bakau. Jakarta: Direktotat Jenderal Perikanan Tangkap Departemen Kelautan dan Perikanan.

Nontji, A. 1987. Laut Nusantara. Penerbit Djambatan. Jakarta.

Nybakken, J. W. 1986. Biologi Laut Suatu Pendekatan Ekologi. Diterjemahkan oleh: M. Eidman, Koesoebiono, D. G. Bengen, Malikusworo, dan Sukristrijono. Cetakan Pertama. PT. Gramedia Jakarta

Rusila Noor Y., M. Khazali, dan I.N.N. Suryadiputra. 2006. Panduan Pengenalan Mangrove di Indonesia. Wetlands International Indonesian Programme. PHK/II. Bogor

Salisbury, dan Ross. 1992. Fisiologi Tumbuhan. ITB Press. Bandung.

Soenardjo, N. 1999. Produksi dan Laju Dekomposisi Serasah Mangrove dan Hubungannya dengan Struktur Komunitas Mangrove di Kaliuntu Kabupaten Rembang Jawa Tengah. Tesis. IImu Kelautan.Fakultas Perikanan dan IImu Kelautan. IPB. Bogor

Sukardjo S. 2004. Fisheries associated with mangrove ecosystem in Indonesia: a view from a mangrove ecologist. Biotropia. 23: 1339. 